\title{
The Environmental Conservation: An Ecopedagogical Approach Practiced by Pesantren Annuqayah, Madura
}

\author{
Achmad Fawaid \\ IAI Nurul Jadid, Probolinggo, East Java \\ email:fawaidachmad@gmail.com
}

\begin{abstract}
s
The massive use of plastic in the society indicated the highly unawareness of ecological impacts from the hazard. Pesantren as one of the important institution in Indonesia has a big role to the ground of the ecological knowledge to raise people's environmental awareness. Pesantren Annuqayah, Madura, East Java has advocating and raising environmental awareness of the people surroundings through the activities' against plastic rubbish. Ecopedagogy has been used by pesantren to raise people's awareness. It is an ecoliteracy, in which the volunteer from the pesantren involved to literate local people about the dangerous effect of plastic rubbish and the importance of environmental conservation. For this reason, education is central point in which human be able to learn the importance of nature and their companionship with the earth. Human ecology is part of whole ecosystem in the world. By grounding ecopedagogy, pesantren Annuqayah has been implementing the Prophet Muhammad's saying about environment, Alnadhofah min Aliman, into the practical level. They have successfully managed many contributive programs, such as using local materials to respect biodiversity in their areas, and managing socialization of ecological knowledge either to its students or to the communities' surrounding.
\end{abstract}

\section{Keywords:}

Ecopedagogy, pesantren, and environmental conservation

\section{Introduction}

A concept of "theo-ecology" was firstly coined by Lynn White (1907-1987). His essay entitled "The Historical Roots of Our Ecological 
Crisis" has positioned him as a pioneer of theoecology in Christian Western World (1967, 1203-1207). In the context of Islam, the similar idea has popularized by Sayyed Hossein Nasr in his book entitled The Encounter of Man and Nature: The Spiritual Crisis of Modern Man (1968). Even he has finished the doctoral study in Harvard University on 1956; Nasr argued that he has done something more intelligently than what White has done in the previous year (Foltz 2003, 252).

The term of theoecology has been derived from Greeks; theos means 'God' and logos means 'knowledge'. Theo-ecology or "theology of ecology" is a perception about the presence of God in the problem of entities created by God. Theoecology has been emerged as the first point of modern people spirituality into the religious order revealed by God and His massagers through comprehensive and universal values, including on the environmental issues.

As universal religion, Islam has a big role to grounding theoecology into Moslems and the rest of creations in the world. Grounding theology of nature aimed to deconstruct and re-examine our treatments to the environment. Today, ecological issues, such as forest crisis, water crisis, and the most seriously issues on global warming have represented the disharmony relationship between human and nature.

In Islam, the living in harmony to the nature has basically been implemented by pesantren as the indigenous Islamic education institution in Indonesia. Pesantren has an important role in the field of education, dakwah, and community empowerment, including the environmental preservation. On 5-6 March 2008, in Asrama Haji, Pondok Gede, Jakarta, Department of Religious Affairs and Department of Environment of Republic Indonesia have launched an ambitious program, namely "EcoPesantren". In the first glance, this program has seriously showed the serious efforts to involve Pesatren into the community empowerment for the environmental preservation. Soon after the program has been 
launched until September 2008, there are 475 pesantren being involved into this program. The result showed that pesantren in Indonesia have many efforts to create green area in their environments, including seedling, reforestation, and so forth (ecopesantren.wordpress.com).

However, the program "Eco-Pesantren" has not been integrated to human ecology as the basic principle of the environmental conservation. Without the presence of community's sense, the ambitious program of "ecology" will not be effectively running. As the comparison, the case of Putrajaya, Malaysia, is clear example in the case of how ambitious program called "garden city", but practically contra productive to the high amounts of its community who has suffered caused of dengue fever. This case has represented unrealistic relation between human and ecology (Mulligan 2013, 613-620).

For grounding human ecology, education is the central point in which human being able to learn the importance of nature and their relationship to the earth. Human being is part of the ecosystem in the world. Perceiving the nature without having a sense of such relationship would be useless. Pesantren in Indonesia, including Annuqayah has major responsibility to disseminate Islamic teaching on the one side, and to ground human ecology into santri's awareness in the practical level on the other side.

One of the central issues taken by Annuqayah's pesantren is the massive use of plastics. Through Pemulung Sampah Gaul (PSG) SMA 3 Annuqayah, this Pesantren has actually been involved in taking serious concern on the potential dangerous use of plastics. Hereby, this paper aimed to describe the role taken by Annuqayah's pesantren facing the environmental issue, to examine relationship between ecopedagogy and ecoliteracy, and its practical implementation considering the typology of Annuqayah's ecopedagogy, by which the other pesantren may also take concern in that area. 


\section{'Kalpataru' for Annuqayah}

Annuqayah is one of the oldest pesantren in Sumenep, Madura. It is located at Guluk-Guluk hamlet, Sumenep district, Madura, East Java. This religious institution was built on 1887 by Kiai Syarqawi, and having more than 6000 santris coming from local, regional, national, and even international countries, especially from Singapore, Saudi Arabia, and Malaysia.

Annuqayah has well known as religious institution that having high sensitivity of environment and society condition. There was special division (Bureau of Social Service PP Annuqayah/BPPM-PPA (Biro Pengabdian Masyarakat PP Annuqayab). Since the first founded on 1990, BPPM-PPA has managed various programs for the environmental preservation. Based on this concern, pesantren Annuqayah has been successfully given national award, "Kalpataru", on 1981 during the President Soeharto. ${ }^{1}$

However, the rapid of globalization has brought many changes to this institution. One of them is mode of consumption practiced by santri. For the last decades, many warung (food stalls) have used banana leafs for the wrapped rice (nasi bungkus). But today, they took many uses of plastics for it. There were also diverse instant foods in Annuqayah, which have influenced the ways of santri to perceive and to keep their environment.

It can be simply seen from the toothpaste utilization (pasta gigi or odob. From more than 6000 students in Annuqayah, their packages of toothpaste were thrown out for a month? From 17 formal institutions in Annuqayah today, which has consumed the packaged water, how and where such rubbish is dealt with? Different from the last time, today's Annuqayah has lack of awareness to their environment.

1 It is due to its effort in planting 500 turi trees, 500 kapuk trees, 1500 lamtorogung trees, and 200 akasia trees. These are organized by santri and BPPM-PPA. Read more details, in "Profil Pondok Pesantren Annuqayah", http://berita-annuqayah.blogspot. com/2008/10/profil-annuqayah_14.html 
Control to the rubbish in Public Dump (Tempat Pembuangan Sampah Umum) of Annuqayah was not integrated with the students' awareness to change their 'instant way' of life. Most of them have preferred mie instant rather than cooking. Besides of affecting to the health body, packages of mie instant would also waste for useless. Meanwhile, the formal (government) institutions seen have been decreased in term of their concern to the nature. For instance, the formal curriculum (from government) in Annuqayah has not included yet the issues on environmental conservation into the courses of study.

In the context of religious teaching, Annuqayah has to deal with the rapid change of modernization by strengthening the ethics based on education in the one side, but also grounding the environmental issues and modest way of life into the formal institutions on the other side. The popular Prophet Muhammad's saying: al-nadhûfah min al-imân (cleanliness is a part of faith) should not merely be interpreted in the conceptual term, but also implemented into the practical level.

Meanwhile, some of the formal institutions in Annuqayah which are firstly directed to spread out an ecological awareness still adopted "standards based curriculum": under the control of state, even many pesantren also have "state" formal schools. Unfortunately, these kinds of school are seemingly stronger than traditional teaching in pesantren as their initial basis. Although some of teachers have managed some ideal breakthroughs, including elements of pedagogy into their teachings, they were still needed an integrative support from the others, including its technical supports.

Either scientific or humanistic studies in Annuqayah pesantren have not been able to respond the rapid change of the ways people consume. Consequently, both of them have not given proportional space for enriching students' insights on the importance of taking care to their environment and earth, as their "shared" home. In fact, in the context of 
religious dimension, the appreciation to natural resources is basically a form of thankfulness to Allah.

\section{Ecopedagogy and Ecoliteracy: Intertwined Issues}

Education has a central position to include ecology into curriculums and courses offered to the student. This important role of education has been recognized by United Nations (UN). In Chapter 36 of the 1992 Earth Summit Report went to address the issue in the following manner:

Education is critical for promoting sustainable development and improving the capacity of the people to address environment and development issues. . . . It is critical for achieving environmental and ethical awareness, values and attitudes, skills and behavior consistent with sustainable development and for effective public participation in decision-making (UN 1992, 2).

The UN's concern with ecopedagogy has led this concept as the important issue of international discourses. The international ecopedagogy movement represents a profound transformation in the radical political project that was derived from the work of Paulu Freire (2004) who has known as a critical pedagogy. Ecopedagogy seeks to interpolate quintessentially Freire-an aims of humanization and social justice with a future-oriented ecological politics that radically opposes the globalization of neoliberalism and imperialism on the one hand, and which attempts to foment collective ecoliteracy and realize culturally relevant forms of knowledge grounded in normative concepts such as sustainability, planetary, and biophilia, on the other.

However, R. Khan and V. R. Khan $(2010,12)$ in their important book entitled Critical Pedagogy, Ecoliteracy, and Planetary Crisis has believed that ecopedagogy should not be dogmatically reduced to the theories or practices developed by any particular set of individuals. Rather, for them, the ecopedagogy movement is best perceived as a loosely knit, worldwide association of critical educators, theorists, non-governmental 
and governmental organizations, grassroots activists and concerned citizens engaged in ongoing dialogue and political action that is attempting to develop ecopedagogical praxis in relation to the needs of particular places, groups, and time periods. It means that ecopedagogy should be critical movement grounded in education. However, the critical nature of ecopedagogy is not enough, because this movement should seek to develop at least three variants of ecoliteracy throughout society in the name of a more just, democratic, and sustainable planetary civilization: the technical/functional, the cultural, and the critical. The ecoliteracy is aimed to against the progressive enclosure of culture and nature.

For this purpose, Bowers $(2007,41)$ calls for ecoliteracy into the way in which indigenous (and other) cultures that have long-standing traditions of sustainability in their cultural practices understand and relate to the world and ecopedagogy similarly shares an abiding interest in preserving and supporting the traditional ecological knowledge. To conclude, ecopedagogy therefore seeks to militate for cultural ecoliteracies that can produce multiculturally-relevant knowledge of how diverse cultures differ in their ways of relating to and understanding nature's order, how they may interact with one another in ecologically and educationally beneficial ways, and how they may learn to manifest cultural action for ecologies of freedom.

This would include understanding, for instance, the manner in which: 1) cultures are built out of foundational cosmologies that may work ideologically in ways that are either more or less sustainable to live, 2) develop technologies that are more or less appropriate to the support of biological diversity and social flourishing across history, and 3) organize their collective knowledge via traditions and institutions that are either more or less democratic and integral to the daily life experiences of the people and places such knowledge is meant to support (Khan 2008, 10). 


\section{Student Based Community: PSG}

Annuqayah Pesantren has actually started its concern to the environmental conservation through building BPPM-PPA, but this bureau has only focused on the societal environment. In the educational field, Annuqayah Pesantren has not begun yet to ground a conservative way in preserving the environment. Starting from 2008, when a teacher of SMA 3 Annuqayah, M. Mushathafa involved into the Environmental Teachers' International Convention (ETIC) program, then the program of environmental preservation has just really implemented. It was the forum that managed many training programs for teacher to include the environmental conservation program into the schools activities.

After return from ETIC, Mushthafa, as leader of SMA 3 Annuqayah, has believed that there are three aspects by which a program will be sustainable for longer period. They are normative, inspiring, and practical aspects. In the normative terms, SMA 3 has coordinated by giving assignment to the students to write down the ecological issues in the school magazines. However, this is not well enough to spread to issues and to raise the people's awareness. It needs inspiring facts surrounding us to ground it into our consciousness. By considering about importance of these three aspects, a need for building a student based community is strongly perceived as the important thing.

The ingredients of such three aspects at the first time appear in activity of collecting plastic rubbish on the celebration of Earth's Day 2008. There are 52 students of SMA 3 Annuqayah involved in going into Public Dump of Annuqayah for collecting the plastics. These students are voluntarily recruited through a simple announcement in the school. As the follow-up action, the student based community, namely Pemulung Sampah Gaul (Funky Collector of Rubbish/PSG) was formally built up.

Although focusing on the local community, especially in their school, their activities have received much appreciation from the others, 
including the mass media. Even, the news about it was published in Radar Madura (June 13-14, 2008) and broadcasted in channel Madura Channel (10 June, 2008). To enlarge its socialization, PSG has always actively promoted dangerous potentials of plastics ${ }^{2}$ by building attractive stands in many exhibitions.

Since then, PSG would be more popular. Many schools and institutions have often invited PSG for providing insights and experiences to other students. On June 30, 2008, PSG has presented its organization in Islamic senior high school of Ainul Falah. On November 21, 2008, the presentation was held in Fatayat Nahdhatul Ulama, one of the largest Islamic organizations in Indonesia, and followed to community of mothers on February 13, 2009, in Guluk-Guluk, Madura.

From such experiences, PSG has focused at the first time in socializing knowledge on the important of the nature's conservation, and the dangerous potentials of plastic rubbish for the human health. At the first glance, such practices do not really give much contribution to reduce plastic rubbish, but it was the first thing they have done because they believed that most of the local people have lack of information about it. Moreover, because of their massive socialization, two shops near to with SMA 3 Annuqayah have made a little change by separating rubbish according to its nature of organic and non-organic one.

On the late of 2008, British Council Indonesia has held great program named "School Climate Challenge (SCC) Competition. SMA 3 Annuqayah has responded it by sending the representatives teams: Tim Pupuk Organik (Organic Fertilizer Team), Tim Gula Merah (Brown Sugar Team), dan Tim Sampah Plastik (Plastic Rubbish Team). In accordance with

2 Plastic packages are not just unfriendly to the environment but also dangerous to human health. Kompas (August 6, 2008), national daily newspaper, reported "Sampah Plastik Tahun 2008 Mencapai Lebih 2 Ton Juta" that during 2008, 2.1 ton millions of plastic and any product made of plastic had produced, and 952 ton thousands of it was used as packages, and $80 \%$ of it was potential to be dangerous waste. Plastic gives a practicality of use to the people but has no good impact for the nature. 
such name, each team has focused on their own programs for creating local foods, managing organic fertilizers, and re-cycling plastic rubbish.

After joining with this competition, PSG has more grounded to build a solid foundation of conservation in broader community, not merely in the school, but also in Annuqayah as community. For instance, currently, they have practiced planting 100 seeds in Annuqayah for eco-forestry local environment. Uniquely, they have obtained the seeds not from subsidy or donation, but from their own efforts by selling creative handicrafts from recycling plastics and boxes, such as wallet, bags, and funny invitations.

On October 22, 2011, PSG has held in the first time a very contributive program, named an international video conference, with activists and academician concerning the issue of on the environmental conservation from Europe. As a school which is far away from urban area and lacking of connection, this international conference is very surprising. They held the first online international discussion with Maurtiz Paggabean, a doctoral students in Norwegian University of Science and Technology, Trondhein, Norwegia, about "Generasi Muda dan Tantangan Era Global: Melokalkan Isu-Isu Lingkungan Local” (A Young Generation and Global Challenge: Localizing Global Issues of Environment).

\section{Typology of PSG Ecopedagogy}

PSG's efforts in concerning environmental issues have led us to formulate a kind of typology, in which PSG has really been equivalent with idea of ecopedagogy. The first is foundational cosmology. This is practiced by PSG through seeking some possibilities to deal with huge plastic rubbish in Annuqayah Public Dump. They have understood local ways to settle such issue by focusing at the first time on their students. They went to Public Dump, collected plastic rubbish, and created many kinds of creative handicrafts from such rubbish. They are also involved in socialization of plastic rubbish in other schools and local people. It 
represents on how PSG has built a foundational cosmology of indigenous people in their area.

The second is to develop technology. It has successfully been done through empowering human efforts. It is important to note that reducing plastic rubbish by using high technology does not appreciate human being as the main responsible party for that case. PSG has involved its members to directly go into the places, in which they are able to either solve environmental issues or help local community in understanding the dangerous potentials of plastic rubbish. Tim Gula Merah (Brown Sugar Team) has also been active in cooking local foods, such as kocor, lemper, ketan hitam, and so forth. The ingredients of such foods are taken from local materials.

The last is to organize the collective knowledge. This can be seen on the existence of PSG itself as student based community. Many participants in PSG are voluntarily recruited. It means that there is democratic way to get them aware of preserving their local environment. PSG can be an icon of Annuqayah as representation of people who has collective knowledge to ground eco-pedagogy in the school. PSG is an ecopedagogical movement which has more concerns on environmental degradation, including most importantly plastic rubbish.

\section{Conclusion}

From the discussion above, it can be concluded that PSG has actually represented ecopedagogy in Pesantren Annuqayah through its activity against plastic rubbish. The basic idea of ecopedagogy is ecoliteracy, in which PSG has been involved to literate local people about the dangerous potentials of plastic rubbish and the importance of conservation for environment. By grounding ecopedagogy in Annuqayah, PSG has indirectly implemented the most popular Muhammad's saying about environment, al-nadhâfah min al-imân, into the practical level. They have 
also successfully managed many contributive programs, such as using local materials to respect biodiversity in their areas and managing socialization of ecological knowledge either with other students or themselves through international video conference.

\section{References:}

Bowers, C. A. 2007. Critical Essays on the Enclosure of the Commons: The Conceptual Foundations of Today's Mis-Education. Eugene, OR: Ecojustice Press.

Freire, Paulo. 2004. Pedagogy of Indignation, Boulder, CO: Paradigm Publishers.

and Nita Freire, International Project for Critical Pedagogy, http:/ / freire.mcgill.cal

Kahn, Richard. 2008. From Education for Sustainable Development to Ecopedagogy: Sustaining Capitalism or Sustaining Life? Green Theory \& Praxis. The Journal of Ecopedagogy, Vol. 4, No. 1

and Kahn, V. R. 2010. Critical Pedagogy, Ecoliteracy, and Planetary Crisis, New York: Peter Lang.

Mulligan, K., Elliott, S. J., and Schuster-Wallace, C., "The place of health and the health of place: Dengue fever and urban governance in Putrajaya, Malaysia”, Health \& Place, Vol. 21, May 2013, 613-620.

Nasr, Sayyed Hossein. 1968. The Encounter of Man and Nature: The Spiritual Crisis of Modern Man, London: George Allen and Unwin.

White, Lynn. 1967. The Historical Roots of Our Ecologic Crisis. Science, New Series, Vol. 155, No. 3767, March 10, 1203-1207.

"Sampah Plastik Tahun 2008 Mencapai Lebih 2 Ton Juta", Kompas, August 6, 2008.

"Ecopesantren". http://ecopesantren.wordpress.com/tentang-kami/. Accessed on July 20, 2013.

"Profil Pondok Pesantren Annuqayah", bttp://berita-annuqayah.blogspot. com/2008/10/profil-annuqayah_14.html. Accessed on July 20, 2013.

United Nations Conference on Environment and Development. 1992. Promoting education, public awareness and training. In Agenda 21, 221227. 